\title{
Production and Characterization of Monoclonal Antibodies to a Generic Hapten for Class-Specific Determination of Organophosphorus Pesticides
}

\author{
Mi Soon Jang, Soo Jung Lee, Xiaoping Xue, Hyuk-Man Kwon, ${ }^{\dagger}$ \\ Choon Sup Ra, ${ }^{\dagger}$ Yong Tae Lee, ${ }^{*}$ and Taeowan Chung*

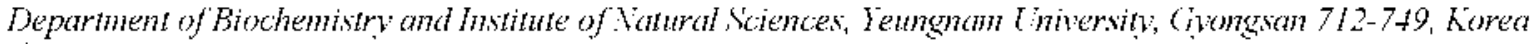

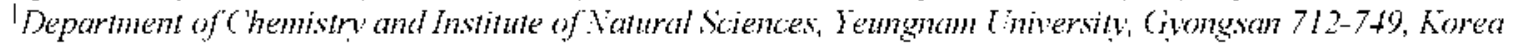 \\ Recened Febratry 18,2002
}

\begin{abstract}
Monoclonal antibodies have been generated against a generic hapten $O .()$-dietlyl ()-(5-carboxy-2fluoropheny 1) phosphorothioate, for the determination of organophosphorus (OP) pesticides in a class-specific manner. In an indirect competitive enzyme-linked immunosorbent assay (ELISA) fomat, employing a heterologous coating antigen these monoclonal antibodies showed desirable properties for use in the class-

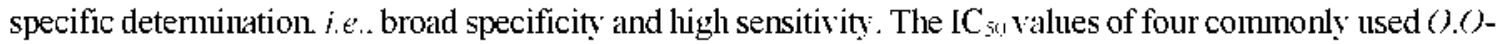
diethỵl OP pesticides were fairly unifom ranging from 0.1 to $0.3 \mu \mathrm{g} / \mathrm{mL}$. The $\mathrm{IC}_{51}$, values of three ().()dimethyl derivatives were between 0.3 and $1.4 \mu \mathrm{g} / \mathrm{mL}$. These values, together with the limits of detection (LOD), were better, in tem of the specificity and sensitivity, compared with the values obtained previously with poly clonal antibodies.
\end{abstract}

Key words: Organoplosphonus pesticides. Class-specific delennination. Enyyme-linked immunosorbent assay. ELISA. Monoclonal antibodies

\section{Introduction}

Organophosphon pesticides are widely used in agricultural and domestic settings. 1,: Although they are known to degrade relatively rapidly. their acute toxicity necessitates more prudent monitoring of their residues in crops and the environment.

Several methods have been reported for the determination of OP pesticides using a variety of teclniques. including gas chromatograplyy and high-perfomance liquid cliromatography: ${ }^{3}$ Although these traditional methods are sensitive and reliable. they suffer from some critical drawbacks: high cost. labor intensive and lengthy sample preparation, and inconvenience for use in the field. Therefore, there is growing demand for more rapid and economical methods for determining pesticide residues. Immmoassays that can meet such demands have recently emerged as an alternative to the traditional methods. Imumunochemical techniques began recently to gain acceptance as a fast sensitive, and costeffective tool for detecting trace amounts of chemicals such as pesticides. ${ }^{4}$

Most of the immunochemical assays developed for the determination of pesticides are aimed at detecting individual pesticides. Class-specific determination of pesticides before chromatographic determination could be an attractive approach for broader pesticide monitoring. If the total quantity of a class of pesticides in a sample can be determined and the quantity is less than the maximum residue limits of certain pesticides in the class. the sample can be eliminated from firther inspection for those pesticides. Since the vast majority of food and envirommental samples turn out to be under maximum residue limits of pesticides. the time and cost saved by this approach may be enormous. The saxings would be greater in the case of major class pesticides. such as organophosphorus and carbamate pesticides. Only a few attempts have been made to develop a class-specific immunoassay for pesticides. An earlier attempt by Banks et al. ${ }^{5}$ using conserved structures of OP pesticides as haptens. produced polyclonal antibodies with broad specificities. but lacked sensitivity: Later attempts by Johnson et $a l^{\circ}$ and Alcocer et $\mathrm{al}^{7}$ yielded significant improvements in sensitivity, but lacked uniform response to analytes.

In an attempt to resolve these problems. we tried to develop an inmunoassay for class-specific determination of OP pesticides using monoclonal antibodies ( $\mathrm{mAb}$ ) against a generic hapten that has a $O . O$-dialkTl thiophosphate group common in OP pesticides. To test the suitability of the nub against the hapten for a class-specific immumoassay, the $\mathrm{mAb}$ generated were characterized by an indirect competitive ELISA in which an analy te competes with the antigen coated on the plate. To the best of our knowledge. this is the first attempt to generate $\mathrm{mAb}$ to a generic lapten to develop a class-specific immunoassay for OP pesticides.

\section{Experimental Section}

Reagents and Instruments. Pesticides were obtained from Dr. Elurenstorfer GmbH (Augsburg. Germany). Ovalbumin. Tween 20. Sephadex G-25. Freund's ilcomplete and complete adjuvant. gelatin. horseradisl peroxidase (HRP)conjugated goat anti-mouse IgG. HAT and HT cell culture media were purchased from Sigma (St. Louis. USA). RPMI 1640. fetal bovine serum. and penicillin-streptonycin were the products of GibcoBRL (Paisley. U.K) and PEG 1500 and $3.3^{*} .5 .5$-tetrametlylbenzidine (TMB) were the products of Boeluringer Manuheim (Mannheim, Gemany). Myeloma 


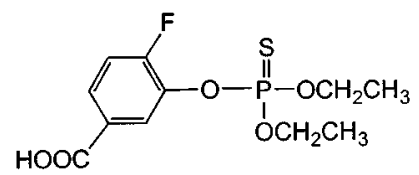

Hapten A

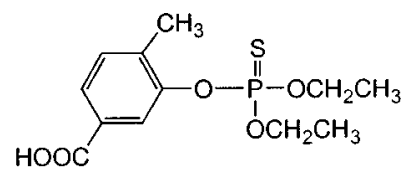

Hapten B
Figure 1. Stuctures of immunizing (Hapten $A$ ) and coating hapten (1laptwal B).

cell line SP 2/0 was provided by Dr. K. J. Hur (Ewha Woman's University. Korca). All the cell culture flasks and plates were obtained from Nunc (Roskilde. Denmark). ELISA plates were washed with a Columbus Plus plate washer from Tecan (Saltzburg. Austria), and well absorbances were read with a Vmax microplate reader from Molccular Devices (Menlo Park. USA). NMR spectra were oblained with a Bruker (Rheinstetten. Germany) ARX spectrometer (300) $\mathrm{MH} /$ ). using tetramethylsilane as an internal standard.

Hapten Synthesis. Hapten A and B shown in Figure l were prepared to be used as immunizing and coating antigen hapten. respectively.

$O, O$-Diethyl $O$-(5-carboxy-2-tluonophenyl) phosphorothioate (Hapten A). To a cold $\left(0^{\circ} \mathrm{C}\right)$ mixiurc of 3-hydroxy4-fluoroben\%oic acid (200 $\mathrm{mg} .1 .28 \mathrm{mmol}$ ) and $\mathrm{KOH}(85 \%)$ (180 mg. $3.2 \mathrm{mmol}$ ) in melhyl alcohol (10 $\mathrm{mL}$ ) was added dropwise dicthyl chlorothiophosphate (362 $\mathrm{mg} .1 .92 \mathrm{mmol}$ ). and the mixture was heated while stirring for 12 h at $65^{\circ} \mathrm{C}$. The reaction mixture was concentrated. and the residuc diluted with ethyl acetate. The acid was cxtracted into $2 \mathrm{M}$ $\mathrm{NaOH}$ solution ( $10 \mathrm{~mL}$ ). acidified by adding concentrated $\mathrm{HCl}$. and then extracted into ethyl acctate $(3 \times 20 \mathrm{~mL})$. The scparated organic layer was washed with water and brinc. dried over magnesium sulfatc. and cvaporated under reduced pressure. Flash chromatography of the residuc on silica gel (clution with chloroform: cthy] acctatc: acclic acid $=30$ : $5:$ l) gave a slightly ycllow solid ( $162 \mathrm{mg} .41 \%$ ). ${ }^{\mathrm{H}} \mathrm{H}$ NMR (300 MH\%. DMSO-d $) ; 7.84(\mathrm{~m} .2 \mathrm{H}) .7 .5 \mathrm{l}(\mathrm{m} . \mathrm{lH}) .4 .26$ (q. $J=7.0 \mathrm{H} \% .2 \mathrm{H}) .4 .24(\mathrm{q} . J=7.0 \mathrm{H} \% .2 \mathrm{H}) .1 .3(\mathrm{l} . J=7.0 \mathrm{H} \%$ $6 \mathrm{H})$.

$O, O$-Diethỵl $O$-(5-carboxy-2-methỵlphenỵ) phosphorothioate (Hajten B). To a solution of sodium cthoxide (4.2 mmol) in elhyl alcohol $(5 \mathrm{~mL})$ at $0^{\circ} \mathrm{C}$ was added dropuise a solution of chỵl 3-hỵdroxy-4-melhylbenzoalc (507 mg. 2.8 mmol) in ethanol ( $3 \mathrm{~mL}$ ). and the mixture was stired for 30 min. Dicthyl chlorothiophosphatc (796 $\mathrm{mg} .4,2 \mathrm{mmol}$ ) was added and the mixture was stirred for an additional $36 \mathrm{~h}$ at room temperature. The reaction mixture was diluted with water ( $2 \mathrm{~mL}$ ). and concentrated under reduced pressure. The residuc was treated with saturated anmonium chloride (5 $\mathrm{mL}$ ) and cxtracted into cllyl acclatc $(3 \times 20 \mathrm{~mL})$. The organic layer was washed with water and brinc. dricd over magnesium sulfatc. and the solvent was craporated. Chromatography of the residuc on silica gel ( $3 \%$ ethyl acclate in hexanc) aflorded $506 \mathrm{mg}(54 \%)$ of 0.0 -dicthyl $O$-(3-carbocthoxy-6melhylphenyl) phosphorothioate as a colorless oil. ${ }^{1} \mathrm{H}$ NMR (300) $\left.\mathrm{MH} \% . \mathrm{CDCl}_{3}\right): 7.87$ (s. lH). $7.77(\mathrm{~m} . \mathrm{lH}) .7 .28(\mathrm{~s} . \mathrm{lH})$. 4.27 (q. $J=6.4 \mathrm{H} \% .2 \mathrm{H}$ ). 4.25 (q. $J=6.4 \mathrm{H} \% .4 \mathrm{H}$ ). 2.37 (s.
$3 \mathrm{H}) .1 .33$ (m. 9H). The product (273 $\mathrm{mg} .0 .89 \mathrm{mmol}$ ) dissolved in chyl alcohol $(25 \mathrm{~mL})$ was mixed with $\mathrm{l} \mathrm{M} \mathrm{KOH}$ (9 $\mathrm{mL}$ ) and stirred for $\mathrm{l} \mathrm{h}$. The reaction mixture was concentrated and diluted with ethy acetate. and then the acid was extracted into $2 \mathrm{M} \mathrm{NaOH}$ solution $(10 \mathrm{~mL})$. The aqucous solution was acidificd with concentrated $\mathrm{HCl}$. and cxtracted into ethyl acetate $(3 \times 20 \mathrm{~mL})$. The organic layer was washed with water and brine. dricd over magnesium sulfate. and the solycnt was craporated. Chromatography on silica gel (chloroform : chyl acctatc : acctic acid $=80)(35$ : 1) gave Hapten B as a white solid (26l mg. 96\%). 'H NMR (300 $\left.\mathrm{MH}_{2}, \mathrm{CDCl}_{3}\right): 7.69(\mathrm{~m} .2 \mathrm{H}) .7 .42(\mathrm{~m} . \mathrm{lH}) .4 .20$ (q. $J=$ $6.5 \mathrm{H} \%, 2 \mathrm{H}), 4.18(\mathrm{q} . J=6.5 \mathrm{H} \% 2 \mathrm{H}) .2 .29(\mathrm{~s} .3 \mathrm{H}) .1 .29(\mathrm{l} . J$ $=6,5 \mathrm{H} \% 6 \mathrm{H})$.

Preparation of Hapten-Carrier Conjugates. Hapten A and $\mathrm{B}$ were conjugated to keyhole limpet hemocyanin (KLH) and ovalbumin (OVA), respectively, to be used as an immunogen and a coating antigen. The conjugation method used was the succinimide ester method. ${ }^{8}$ The conjugates were purilied by gel liltration on Sephadex G-25. The cluted conjugates were dialy/ed against water and then frecze-dricd before storage at $-800^{\circ} \mathrm{C}$.

Immunization, BALB/c lemale mice ( 8 wecks old) were immunized subcutancously with I : I mixture (v/s. 200 $\mu \mathrm{L}$ ) of Hapten A-KLH conjugate (50 $\mu \mathrm{g})$ in PBS and Frcund's complete adjuvant. Two and four wecks after the initial injection. booster injections were given intraperitoncally with the same amount of immunogen cmulsificd with incomplete Freund's adjuvant. One weck after each booster injection. mice were tail-bled and antiscra were tested for anti-hapten antibody titer by a noncompetitive indirect ELISA using a homologous coating antigen (Hapten A-OVA). After a resting period of three wecks following the third injection. mice selected as the donors of splecn cells for hybridoma production received a final intraperitoncal injection with the same amount of conjugate in PBS. The mice were sacrificed for cell fusion 3 days after the final injection.

Cell Fusion. SP $2 / 0$ murine mycloma cells were cultured in RPMI 1640 media supplemented with $20 \%$ felal bovine scrum and $1 \%$ penicillin-streptomycin. Cell fusion procedures were carricd out essentially as described by Galfre and Milstein." Mice splenocytes were mixed with the mycloma cells at the ratio of $5:$ I and centrifuged. One mL of PEG 1500 at $37^{\circ} \mathrm{C}$ was dropped to the cell pellet over 1 min. After addition of $\mathrm{l}+\mathrm{mL}$ of noncomplete media (RPMI + penicillin-streptomycin) over 5 min. the cells were left aside for 5 min. The fused cells were then spun down and resuspended at an approximate density of $4 \times 10^{3}$ cells per $\mu \mathrm{L}$ of HAT selection media before they were distributed in a dose of $100, u$ L per well in 96-well culture plates which were previously coated with fecding cells. The HAT media consisted of RPMI minimal media supplemented with 100 $\mu \mathrm{M}$ hypoxanthine. $0.4 \mu \mathrm{M}$ aminopterine and $16 \mu \mathrm{M}$ thymidine. Half of the media in the wells were replaced by fresh HAT media exery 3 rd day. The HAT media were changed to HT media with no aminopterin. when most of the nonfused cells were climinated. 
Hybridoma Selection and Cloning. Ten days after cell fusion. when the hybridoma cells were grown to approximatcly 30 to $40 \%$ confluent in the well. culture supernatants were collected and screcned for the presence of anti-hapten antibodies. Noncompetitiye indirect ELISA using Haplen AOVA as a coating antigen was used for hy bridoma screening. Selected hybridomas were cloned by limited dilution and stable antibody-producing clones were cxpanded. Competitive indirect ELISA using Hapten B-OVA as a coating antigen was then employed to determine if the antibodies from the finally expanded clones could recognize the analy te and the coating antigen on a competitive basis. Selected clones were cryopreserved in liquid nitrogen.

Enzyme-Linked Immunosorbent Assays. In noncompctitive indirect ELISA. all incubations. except for antigen coating. were carried out at room temperature. Microtiter plates (96 well) were coated with Hapien A-OVA (1000 $\mu \mathrm{g} /$ $\mathrm{mL} .100 \mu \mathrm{L} / \mathrm{wcll})$ in $50 \mathrm{mM}$ carbonatc-bicarbonatc buffer (pH 9.6) for $16 \mathrm{~h}$ at $4{ }^{\circ} \mathrm{C}$. The wells were washed 5 times with PBST solution ( $10 \mathrm{mM}$ PBS containing $0.05 \%$ Twcen 20. $\mathrm{pH} 7.4$ ) and then blocked by incubation with $200 \mu \mathrm{L} /$ well of $2 \%$ gelatin solution. After another washing step. the wells were incubated with $100 \mu \mathrm{L}$ of scrially diluted antibodies in PBST for $\mathrm{l} \mathrm{b}$. The wells were washed and $\mathrm{l}(00)$ $\mu \mathrm{L} /$ well of horscradish peroxidase (HRP)-conjugated goat anti-mouse $\lg$ G diluted $\mathrm{l}: 2000$ in $10 \mathrm{mM}$ PBST was added. After incubation for $1 \mathrm{~h}$ and washing step. $100 \mu \mathrm{L} / \mathrm{wcll}$ of a TMB solution (400 $\mu \mathrm{L}$ of $0.6 \%$ TMB-DMSO and $100 \mu \mathrm{L}$ of $1 \% \mathrm{H}_{2} \mathrm{O}_{-}$diluted with $25 \mathrm{~mL}$ of citratc-acctatc bulfer. $\mathrm{pH}$ 5.5) was added to the wells and the reaction was allowed to go for $10 \mathrm{~min}$. The reaction was stopped by addition of 50 $\mu \mathrm{L} /$ well of $2 \mathrm{M}$ sulfuric acid and absorbance was read at 450 min.

Checkerboard assays. in which scicral dilutions of antibodies were titrated against varying amounts of the coating antigen (Hapten B-OVA). were used to select the most suitable antibody and to have a rough cstimatc of appropriatc antigen coating and antibody concentrations for compctitive assays. Compclitive assays were performed as follows. To microtiter plates coated and blocked as described above. $50 \mu \mathrm{L} / \mathrm{wcll}$ of $\mathrm{OP}$ pesticide standards dissolved in 10 $\mathrm{mM}$ PBS containing $10 \%$ methanol and $50 \mu \mathrm{L} / \mathrm{wcll}$ of antibodies diluted with PBST were added. The subsequent steps were the same as those in noncompetitive assays. Competition curves were obtaincd by plotling absorbance against the logarithm of analyte concentration. Signoidal curves were fitted to a four-paraneter logistic equation. ${ }^{\text {'i }}$ from which $\mathrm{IC}_{5 \mathrm{~s}}$ values (concentration at which binding of the antibody to the coating antigen is inhibited by $50 \%$ were detcrmined.

\section{Results and Discussion}

Synthesis of Immunizing and Coating Antigen Haptens. The purpose of this study is to develop an immunoassay that can detcrmine organophosphorus pesticides in a class-specific manner. not individually. Since most of the commonly used
Table 1. IC 50 and limit of detection values of $O, O$-dicthy $O P$ pesticides using $\mathrm{m} / \mathrm{bs} \mathrm{H}-7$ and $\mathrm{H}-9$

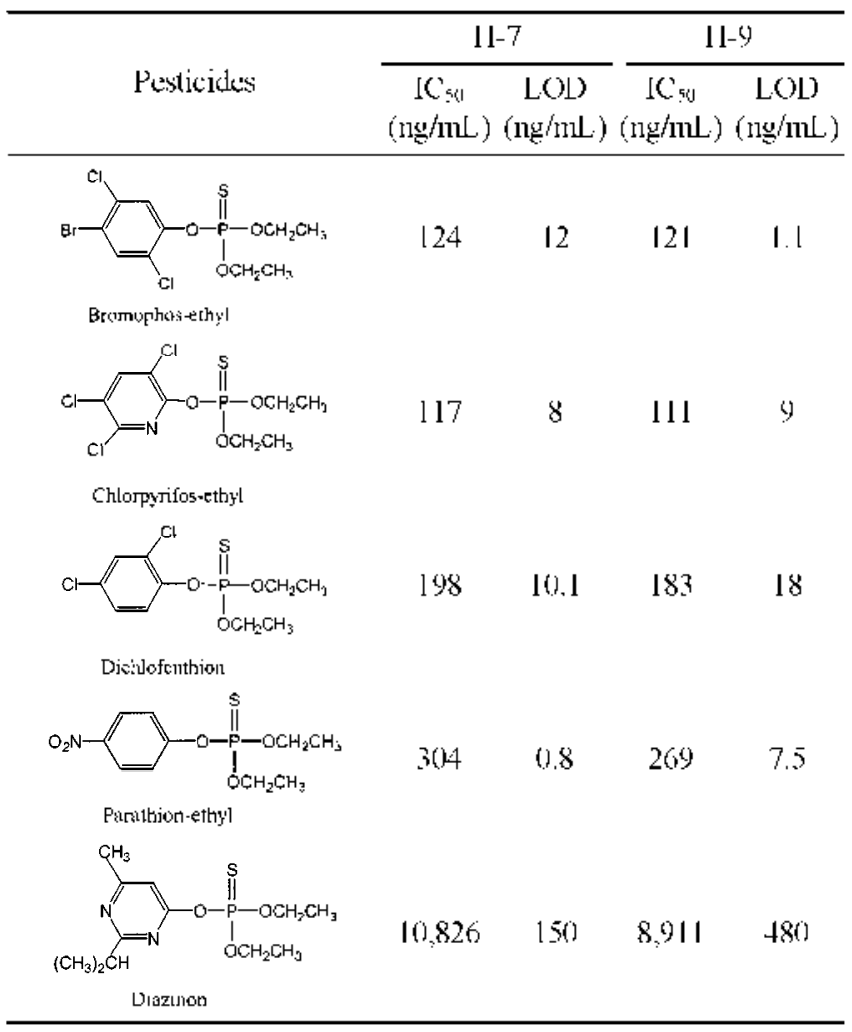

$O P$ pesticides have an aromatic ring and thiophosphate moictics. we decided to synthesize a generic immunizing hapten having both moictics to generate antibodics with a high allinity to the pesticides. Howerer. we tricd to climinate any bias toward a particular structure cxistent in commonly used pesticides in order to generate antibodies with relatively uniform aflinities to the pesticides. The stratcgy we adopted was to avoid an aromatic ring with a substitucnt at para position which is present in parathion. and to place instcad a substituent on the aromatic ring that is absent in commonly used pesticides. Hapten A designed on this ground gave quite satisfactory results as described below.

Immune Response of Mice to the Hapten Conjugate. To sce if the immunogen is capable of cliciting the immunc response in the mice. antisera from three mice injected with Hapten A-KLH were collected after 2nd and 3rd booster injections and tested for the presence of antibodics recogni\%ing the immunizing hapten by a noncompetitive indirect ELISA using the homologous coating antigen (Hapten AOVA). All mice sera cxhibited high lescls of polyclonal antibodies: the titer values after the 3 rd injection were 0.25 0.79 at $1 / 160000$ dilution. The titer values after the $3 \mathrm{rd}$ injection were 2 to 3 times higher compared with those after the 2nd injection.

Production of Hybridomas and Cloning. Two mice that showed higher titers of polyclonal antisera compared with the third one were used for cell fusion. The splecen cells from these animals were fused with SP $2 / 0$ murine mycloma cells and the resulting fused cells were tested for the presence of 
Table 2. IC 50 and limit of detection values of $O, O$-dimethyl $O P$ pesticides using mabs $11-7$ and $11-9$

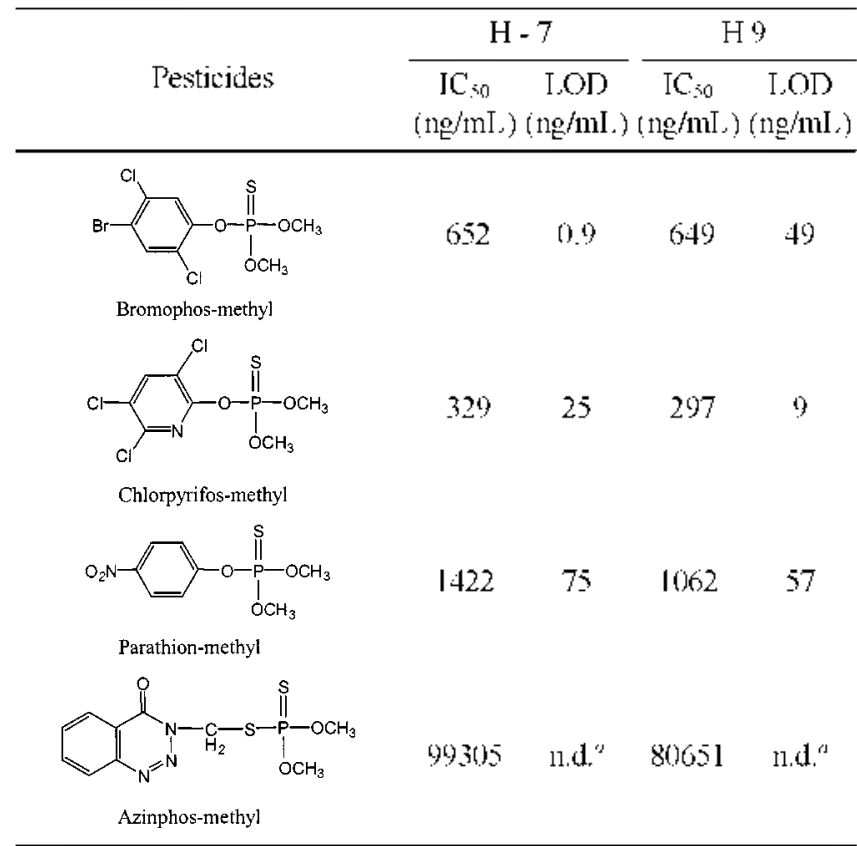

"nol detemmed.

antibodies recognizing the immunizing hapten in the same manner as described above for polyclonal antiscra. Oul of lifty live wells containing hybridona cells. Jour wells were found to have cells producing anti-Hapten A antibodics. The cells in the four wells were subscquently subjected to cloning procedures and the clones oblained were screcned by a competitive indirect ELISA using parathion and Hapten B-OVA (coating antigen) as compctitors. Two clones. designated $\mathrm{H}-7$ and $\mathrm{H}-9$. were linally selected for further characterizations.

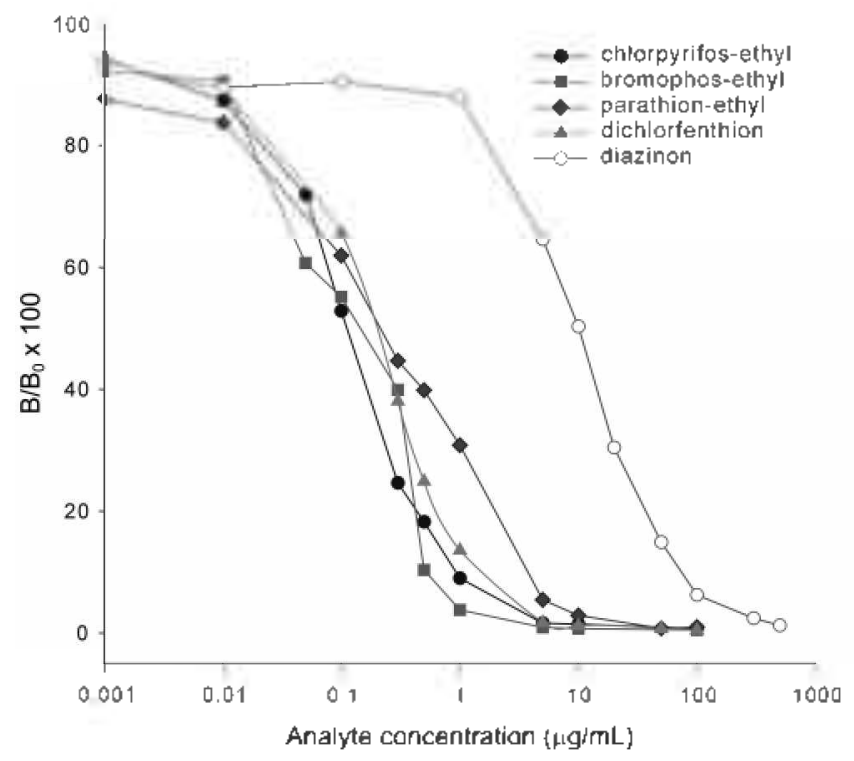

Figure 2. Dose-response curves for $O, O$-diethyl OP pesticides using mAb H-7.

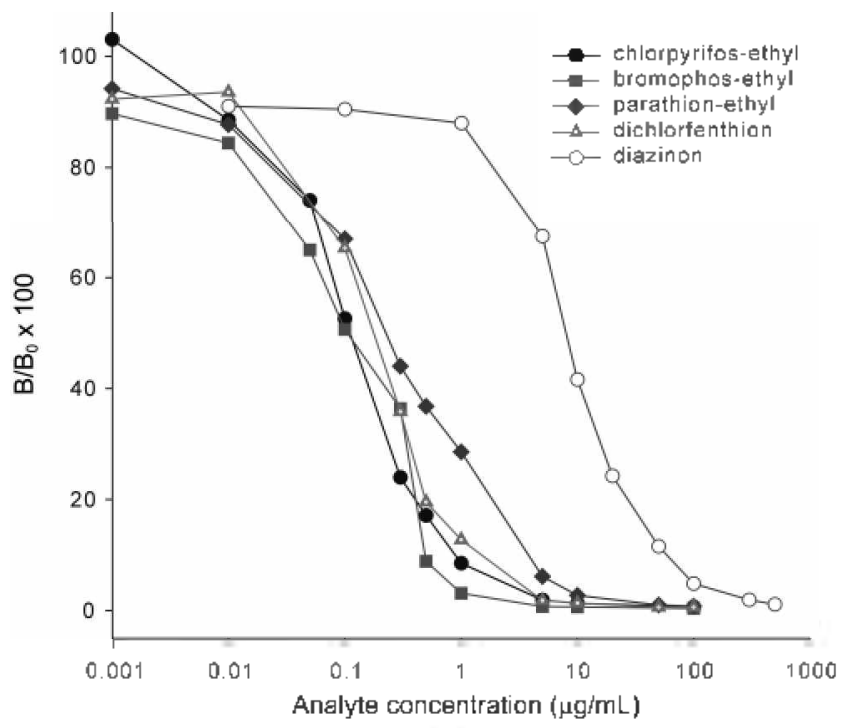

Figure 3. Dose-response curves tor 0,0 -diethyl OP pesticides using $m \Delta b \mathrm{~b}-9$.

Characterization of the mAbs. The mAbs from the wo hy bridoma clones were tested for their specificitics toward 9 dillerent OP pesticides. Five of them were $O . O$-dicthyl OP derivatives and the rest were $O$.O-dimethyl derivatives. As shown in Figure 2. in an indirecl competitive ELISA using Hapten B-OVA as a coating antigen. $\mathrm{mAb} \mathrm{H}-7$ showed broad specificities toward the ethyl derivatives. The specificitics were lairly uniform cxcept with diarinon which was very low. Almost the same pattem was observed with mAb $\mathrm{H}-9$ (Figure 3). In both cases the slopes of the inhibition curves were sharp and the backgrounds were very low. The IC values of the $O . O$-dicthy $\mathrm{OP}$ derivatives cxcluding diazinon werc $0.12-(0.30 \mu \mathrm{g} / \mathrm{mL}$ using $\mathrm{H}-7$ and $0.11-0.27 \mu \mathrm{g} / \mathrm{mL}$ using $\mathrm{H}-9$ (Table $\mathrm{l}$ ). The reduced affinity of both antibodics toward diazinon could be explained by the unique aromatic

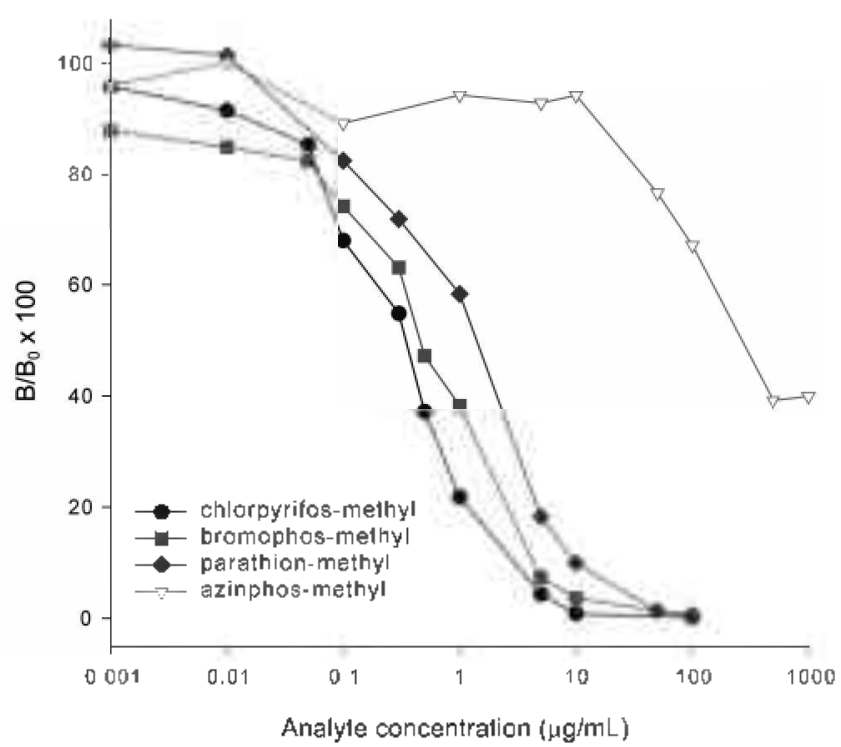

Figure 4. Dose-response curves for (), ()-dimethyl OP pesticides using $m \wedge \mathrm{b} \mathrm{H}-7$ 


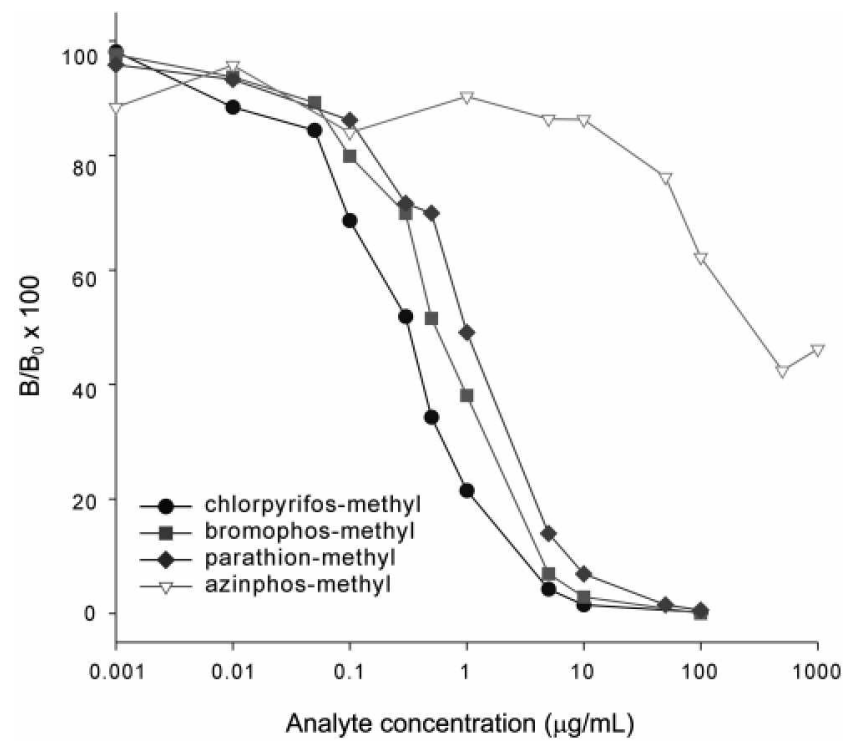

Figure 5. Dose-response curves for $O .0$-dimethyl OP pesticides using $m A b \mathrm{~b}-9$.

structure of diarinon (bulky alkyl substituent).

Inhibition curves for four $O . O$-dimethy $1 O P$ derivatives. using H-7. is shown in Figure 4. The specificilics are lairly uniform. except with aximphos-methyl. which was very low. Almost the same patten was obsericd with mAb H-9 (Figure 5). The $\mathrm{IC}_{5(1)}$ values of the $O . O$-dimelhyl $O P$ derivatives. cxcluding a ainphos-methyl. were somewhat higher than those for the ethyl derivatives: 0.33-1.42 $\mu \mathrm{g} / \mathrm{mL}$ using $\mathrm{H}-7$ and $0.30-1,06 \mu \mathrm{g} / \mathrm{mL}$ using $\mathrm{H}-9$ (Tablc 2). This aflinity difference is expected. since the immunizing hapten was an ethyl derivative. These results suggest that both the aromatic ring and the thiophosphate group were insolved in inducing antibodies recognizing $O P$ pesticides. Since the two mabs show almost the same specilicitics toward the analytes tested. it is quite probable that they were descendants of a single ancestor hybridoma cell.

The ELISA dereloped by Banks et al. "for the detection of multiple OPs had a problem of poor sensitivity: the lowest $\mathrm{IC}_{5 \mathrm{j}}$ value was $c a .5 \mu \mathrm{g} / \mathrm{mL}$. Thereforc. performance of the ELISA we developed is better in terms of sensitivity than that of Banks et at. The ELISA developed by Johnson et af ${ }^{6}$ for the decection of multiple OPs had a problem of nonuniform response to the pesticides: the $\mathrm{IC}_{30}$ ratio between chlorpyrilos and parathion was $c a$. 1/1000). Therefore. the performance of the ELISA we developed is better in ternis of uniformity of response than that of Johnson $a$ al.

To confirm that the mAbs were specilic only to organophosphorus pesticides. some carbamate pesticides were tested to sec if they were recognized by the antibodics. None of them showed any sign of inhibition of antibody binding to the coating antigen (data not shown). Therelore. the mAbs produced from hy bridomas $\mathrm{H}-7$ and $\mathrm{H}-9$ were specific only to OP pesticides.

\section{Conclusion}

With the aim of dereloping an ELISA for the detection of organophosphorus pesticides in a class-specilic manner. we produced monoclonal antibodics against a gencric $O P$ hapten. $O, O$-dictlyy 1-O-(5-carboxy-2-fluorophenyl) phosphorothioatc. and cxamined the characteristics of the antibodics with a competitive indirect ELISA. The antibodies showed a quite unilorm specilicity to $O P$ pesticides. Although this method does not meet the ideal criteria for uniform response to all OP pesticides. it works well for several commonly used pesticides. Therefore. the present work demonstrates the leasibility of using immunochemical methods for the detection of multiple OP pesticides.

Acknow ledgment. We are grateful to Won Young Lec and Won Chul Park for their helves in the preparation of the manuscript. This work was supported by a grant from Korca Rescarch Foundation (KRF-199\%)-005-D000155).

\section{References}

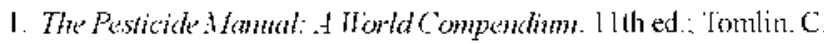
I) S. . lid.: The I3ritish Crop Prolection Council: Iiarnham. Surrey. U.K.. 1997.

2. Racke. K.D. Ren: Enimon. Contam. Foricol 1991. 137. 1-150.

3. AOAC International. Official Methods of .Analysis. 18th ad: Arlington. VA. 1995: Section 970.52

4. I lemion. M.-C : I3arcelo, I) And. (7hm tcta 1998, 362. 3-34.

5. I3anks. I. N.: Chaudry, M. Q.: Matthews, W. A.: I Javerly: M.: Wathins. T.: Northyay. B. T. food lgric. Inmtwot 1998. 70. 349361 .

6. Johnson. . C. C. Van Emon. I. M.: Pullman. D. R.: Keeper. K. R. $d$. Agric. Food (7nem 1998, t6 3116-3123.

7. Aleocer. M. I. C.: Dillon. P. P.: Manning. B. M.: Dowen. C.: [.ee.

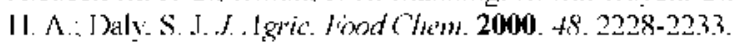

8. McAdam. D. P. Hill. A. S.: Beaslcy: H. L.: Sherritt. T. H. f. tgric. Food hem. 1992. 10. 1466-1470.

9. Galt'e. G.: Miltstein. C. Hethods Enzymol 1981. 73. 3-46.

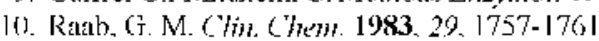

